\title{
PROBLEMS OF THE ITALIAN PEACE TREATY: ANALYSIS OF CLAIMS PROVISIONS AND DESCRIPTION OF ENFORCEMENT
}

\author{
Walter Stering Surrey*
}

"An Agreement on an Agreement on an Agreement."

The Allied and Associated Powers and Italy "desirous of concluding a treaty of peace which, in conformity with the principles of justice, will settle $e^{2}$ questions still outstanding ... have therefore agreed to declare the cessation of the state of war and for this purpose to conclude the present Treaty of Peace ..."3 (February 10, 1947).

"As an integral part of the measures which are now being taken to restore $e^{4}$ normal financial and economic relations between our countries ... the Government of the United States of America and the Government of Italy have reached an understanding providing for mutual renunciation of claims and for related agreements ...." (August $x_{4}$, x947).

"The Embassy of the United States of America ... has the honor to refer to previous correspondence ... and to conversations ... with regard to the desirability of clarifying the meanings of the phrases in the Memorandum of Understanding. ... [August I4, r947]. If the Government of Italy is prepared to give its approval to the foregoing agreement 'clarifying the meaning of phrases' in the Memorandum of Understanding ... [ [this] agreement shall be considered as having entered into effect ${ }^{7}$ as of the date ..." of such approval (February 24, 1949). ${ }^{8}$

\section{I}

\section{INTRODUCTION}

With all the good will on both sides, a settlement of economic issues and, in particular, claims by a victorious state on behalf of itself and its nationals against a defeated state, are not easily resolved in prínciple nor expeditiously executed in

- Member of the District of Columbia and New York bars. Formerly Assistant Legal Adviser, Department of State. Deputy United States negotiator of the Economic Agreement with Italy, of August I4, I947 (the "Lombardo Agreement"). The opinions expressed in this article are, entirely those of the author and in no way are intended to indicate the views of the Department of State.

With apologies to Gertrude Stein.

Italics supplied.

${ }^{3}$ Treaty of Peace with Italy signed at Paris, February 10, I947. 6r Stat. 1245, 80th Cong,, Ist Sess. (r947).

Italics supplied.

${ }^{-}$Memorandum of Understanding Between the Government of the United States of America and the Government of Italy Regarding Setternent of Certain Wartime Claims and Related Matters, signed at Washington, August 14, 1947 .

- Italics supplied.

? Ibid.

SNote verbal from the Embassy of the United States of America to the Ministry of Foreign Affairs, Italy, February 24, I949. The Government of Italy accepted the proposals in a note of the same date, addressed to the United States Embassy at Rome. 
practice. United States-Italian relations, since Italy's unconditional surrender and assumption of a somewhat novel co-belligerency status with the Allies in the fall of 1943, have, on the whole, been very good. Negotiations between the two countries on the settlement of claims against Italy have from the days of the negotiations on the Treaty of Peace been more than amicable and friendly. But amicable and friendly negotiations, and successive agreements designed to settle claims issues once and for all, cannot be cashed in the bank by United States claimants.

It is my purpose in examining into the question of claims held by the United States and its nationals against Italy, to determine what has been agreed upon in the various successive "final" agreements, to review how these agreements have been executed, and perhaps thereby to be able to draw some conclusions as to possible procedures which may temper the views of some claimants that the problem is one consigned to the ages.

In the negotiations of the Italian Treaty of Peace, the United States sought to insure that the terms imposed on Italy by way of reparations would not be so onerous as to retard Italy's reestablishment of sound economic conditions and healthy relations with the other members of the family of nations. At the same time, the United States sought to assure that United States nationals, who had justified claims against Italy arising out of the war, would be protected in the satisfaction of those claims. Thus the United States, together with most other signatories, sought no reparations for its own national treasury, as distinguished from satisfaction of justified claims of its nationals for the benefit of their individual pockets.

Accordingly, reparations primarily from industrial equipment designed for the manufacture of war material, and from current production, to be paid over a maximum period of seven years, were provided only for the Soviet Union (to the tune of $\$ 100,000,000),{ }^{9}$ Albania $(\$ 5,000,000),{ }^{10}$ Ethiopia $(\$ 25,000,000),{ }^{11}$ Greece $(\$ 105,000,-$ $000),{ }^{12}$ and Yugoslavia $(\$ 125,000,000) .^{13}$

The United States, together with most of the Allied and Associated Powers, restricted its claims to two categories: first, utilization of Italian assets within the United States to the extent, and only to the extent, necessary for the satisfaction of its claims and those of its nationals, other than claims fully satisfied under other Articles of the Treaty, ${ }^{14}$ and second, claims for the return of United States property, and property of its nationals, located in Italy, or where such property could not be returned, or where, as a result of the war, a United States national suffered a loss by reason of injury or damage to his property in Italy, compensation in lire to the extent of two-thirds of the amount necessary, as of the date of payment, to purchase similar property or to make good the loss suffered. ${ }^{15}$

- Treaty of Peace with Italy, Part VI, Section I, Article 74, paragraph A, sub-paragraph I.

${ }^{10}$ Treaty of Peace with Italy, Part VI, Section I, Article 74, paragraph B, sub-paragraph 1.

${ }^{11}$ Ibid. 12 Ibid. ${ }^{13}$ Ibid.

${ }^{14}$ Treaty of Peace with Italy, Part VII, Section II, Article 79, paragraph I.

16 Treaty of Peace with Italy, Part VII. Section I, Article 78 . The question of the return of property by Italy from the territory of any of the United Nations is not dealt with herc. It is covered by Section II, Article 75 of the Treaty of Peace with Italy. 


\section{Italian Assets in the United States}

Article 79 of the Treaty provides certain basic rules for the utilization of Italian assets in the United States.

First, it gives the United States ${ }^{16}$ the right to retain and deal with in any manner all property in the United States of Italy and its nationals, as of the date of the coming into force of the Treaty, to the extent such property is required for the settlement of claims of the United States and its nationals against Italy and Italian nationals. ${ }^{17}$

Second, any amount in excess of the amount of such claims is to be returned to Italy. ${ }^{18}$

Third, United States law is to govern the liquidation or disposition of Italian property in the United States and the rights of the Italian owners in such property. ${ }^{19}$

Fourth, Italian industrial property in the United States need not be returned nor counted in the calculation of the amounts of Italian property which can be retained by the United States. ${ }^{20}$

Fifth, excluded from property which may be retained is any property of the Italian Government used for consular or diplomatic purposes; ${ }^{21}$ property belonging to religious or private charitable institutions where used exclusively for religious or charitable purposes; ${ }^{22}$ property of natural persons of Italian nationality permitted to reside in the United States or in other United Nations; ${ }^{23}$ property rights arising since the resumption of trade and financial relations between Italy and the United States; ${ }^{24}$ and literary and artistic property rights. ${ }^{25}$

Sixth, the Italian Government undertakes to compensate Italian nationals whose property is taken. ${ }^{26}$

Both prior to and subsequent to the signing of the Treaty of Peace, the United States made substantial contributions to the relief of Italians. By its contributions to UNRRA, by civilian supplies furnished under a military relief program, as well as by contributions through private channels, aid from the United States constituted an important factor in assisting the Italian relief and recovery programs. Our official policy was designed to afford Italy an opportunity to set up a free democratic

10 These rights are, of course given to all of the Allied and Associated Powers. These are listed in the first introductory paragraph to the Treaty as follows: "The Union of Soviet Socialist Republics, the United Kingdom of Great Britain and Northern Ireland, the United States of America, China, France, Australia, Belgium, the Byelorussian Soviet Socialist Republic, Brazil, Canada, Czechoslovakia, Ethiopia, Greece, India, the Netherlands, New Zealand, Poland, the Ukrainian Soviet Socialist Republic, the Union of South Africa, and the People's Federal Republic of Yugoslavia."

${ }^{17}$ 'Treaty of Peace with Italy, Part VII, Section II, Article 79, paragraph 1.

${ }^{28}$ lbid.

${ }^{10}$ Treaty of Peace with Italy, Part VII, Section II, Article 79, paragraph 2.

${ }^{30}$ Treaty of Peace with Italy, Part VII, Section II, Article 79, paragraph 4.

21 Treaty of Peace with Italy, Part VII, Section II, Article 79, paragraph 6, sub-paragraph (a).

22 Id., sub-paragraph (b).

24 Id., sub-paragraph (d).

${ }^{23} I d$., sub-paragraph (c).

20 Treaty of Peace with Italy, Part VII, Section II, Article 79, paragraph 6, sub-paragraph 3. 
system of government. We recognized that chaos, hunger, and desperation, while a barren soil for the birth of a democratic system of government, were admirably suited for the quick growth of a dictatorship, including a communist dictatorship. Thus, our policy was to provide dollar aid wherever the furnishing of such aid was possible.

One possible source of funds clearly concerned Italian vested and blocked property in the United States. At the time of the signing of the Treaty of Peace, there was in the United States approximately $\$ \mathrm{r}_{5}, 800,000$ of vested Italian property, ${ }^{27}$ and $\$ 50,000,000$ of blocked Italian property. ${ }^{28}$ If a way could be found to ascertain the amount of legitimate claims of United States nationals against Italy which could be satisfied out of such funds, the United States was prepared to waive its governmental claims against such assets, and return the balance to Italy. The claims of United States nationals to be satisfied from Italian assets fell primarily into two categories: (a) personal injury claims, such as for maltreatment of members of the armed forces while prisoners of war in Italy, or maltreatment of United States civilians during the war by Italians; and (b) claims for damages caused by Italians to property owned by United States nationals, or to property in which such nationals had an interest, where the property was located outside of Italy.

Not surprisingly, attempts by the armed services and the State Department to secure information from potential claimants did not reveal even enough information to calculate intelligently the probable size of such claims. Two courses of action were available. First, the United States could set a time limit for the filing of such claims by its nationals; it could then satisfy all of such claims so filed and determined to be valid out of Italian assets in the United States, returning the balance of the assets to Italy. This course of action gave rise to certain fundamental objections, both with respect to our domestic policy as well as our foreign policy. The Treaty had provided no time limit for satisfying claims out of Italian assets in the United States. For the United States executive branch to impose any but a rather lengthy period of time during which claims might be filed would have resulted in working injustices against legitimate claimants. On the other hand, the need for dollars by Italy was an immediate one, and of critical importance to the future political destiny of Italy and the free world.

The executive branch therefore decided to follow a second course of action. It determined to retain a certain amount of the assets, estimated to be adequate for satisfying legitimate claims, and to return the balance to Italy immediately. On further examination, it was subsequently determined to be administratively easier to return all vested and blocked assets to Italy, with certain exceptions, but provide for

\footnotetext{
${ }^{27}$ This figure is an approximation made from certain records of the United States Government. Approximately $8 \mathrm{I} / 29$ million dollars of vested property has been refunded.

${ }^{28}$ This is a very general estimate. The greater percentage has been returned through a procedure whereby the Italian authorities certify to the holding banks that unblocking is within the terms of the unblocking agreement between the two countries. No official record of the amount unblocked is available to the Governments.
} 
Italian payment of dollars to the United States. This was accomplished in the "Memorandum of Understanding Between the Government of the United States and the Government of Italy Regarding Italian Assets in the United States of America and Certain Claims of United States Nationals," ${ }^{29}$ signed and entered into force on August 14, 1947. Under this agreement, the United States agreed to effect the return of vested Italian assets under the Trading with the Enemy Act, and to release blocked Italian property. ${ }^{30}$ Italy, on its behalf, agreed to pay $\$ 5,000,000$ in United States dollars, on or before December 3I, I947, to be utilized "in such manner as the Government of the United States of America may deem appropriate, in application of the claims of United States nationals arising out of the war with Italy and not otherwise provided for." ${ }^{\text {31 }}$

This method for settling the claims is a very satisfactory one. The legitimacy of the claims of United States nationals is determined by their own government. This is certainly preferable, in so far as such nationals are concerned, to leaving them to deal with a foreign government, where language differences, varying legal systems, and mere physical distances involved are almost certain to complicate and harass the claimant. Moreover, it eliminates the claims issue as a potential source of dispute between the two governments. It is also likely to be preferable, from the claimants' viewpoint, to adjudication by an international tribunal. Procedures before such a body are always likely to be more complicated, more expensive, and time consuming.

This method of settlement is particularly advantageous in those cases where the relations between the two governments are not of the best, as witness the settlement reached with Yugoslavia with respect to payment for expropriation of property in Yugoslavia owned by United States nationals, or in which such nationals had an interest. ${ }^{32}$

\footnotetext{
${ }^{20}$ This memorandum was one of the two memoranda which, together with annexes, constituted the agreement reached between the United States of America and Italy on financial and economic problems arising out of the Treaty of Peace. The entire agreement is commonly referred to as the "Lombardo Agreement" after the Italian negotiator, Ivan Matteo Lombardo. For convenience sake the memorandum here referred to, dealing with Italian assets in the United States, shall be referred to as Memorandum of Understanding I.

${ }^{30}$ Memorandum of Understanding I, Article I, paragraphs I (a) and I (b). The United States was not required to return assets: (I) belonging to the Italian Fascist Party, any closely affiliated organization, or any person who was a member of such party or organization after September 8 , r943; (2) any person, firm, or organization convicted of violating any of the statutes set forth in section 34 (a) of the Trading with the Enemy Act; (3) any person, firm or organization convicted of war crimes or of having collaborated with an enemy country after September 8, 1943, or any person, firm or organization charged with having committed such action until officially acquitted or cleared; (4) a corporation or organization organized under the laws of any country other than Italy or Trieste; (5) any individual who was at any time after December 7, 194I, a citizen or subject of a nation other than Italy with which the United States had since December 7, 1941, been at war; (6) any individual voluntarily resident at any time since December 7, I94I, within the territory of any nation other than Italy with which the United States had been at war since December 7, 194r.

${ }^{a 1}$ Memorandum of Understanding I, Article II.

s9 Agreement between the Governments of the United States of America and the Federal Peoples Republic of Yugoslavia regarding pecuniary claims of the United States and its nationals, July 19, 1948. Under this agreement Yugoslavia made available $x 7$ million dollars in "full settlement and discharge of all pecuniary claims of the Government of the United States . . . all claims of nationals of the United States
} 
It is to be recognized that there are inherent weaknesses in the procedure. On the one hand, it is often difficult at the time of negotiating such an agreement to estimate the potential size of all legitimate claims which may exist. ${ }^{33}$ The tendency in such cases is for the government of the claimants to place the amount of the lump sum settlement sufficiently high to offer a reasonable, or even more than reasonable, assurance of the sum being adequate to satisfy all possible legitimate claims which may subsequently be filed. The agreement could provide, as in the case of the Yugoslav Settlement, that any balance remaining will be returned to the liable government. However, politically, both governments may not wish to postpone a final settlement. The government liable for the satisfaction of the claims would not find it desirable to subject itself to future liability if the sum proves inadequate, and in such circumstances the claimant government may not be agreeable to committing itself to returning any unused balance. ${ }^{34}$ In such circumstances the mere procedure of negotiating a settlement involves bargaining over the figure, and that in turn tends to create a climate of feeling on both sides of the table to settle the issue once and for all.

But the difficulties in following such a procedure do not appear to override the advantages. To be able to settle the issue as between governments is certainly worth the calculated risk to both governments in making the "guesstimate" as to the potential size of valid claims.

No procedure has been established for hearing or adjudicating claims against Italy for personal injury, including loss of life, or for war damages to property located outside of Italy. There is some likelihood that the Congress will authorize the War Claims Commission to deal with these claims. ${ }^{35}$ Any United States national having such a claim should, however, place his claim on record. This should be done by filing a claim in the form of a sworn statement in duplicate with the Department of State. The claim should be in narrative form setting forth a clear chronological statement of the essential facts, covering such material facts as citizenship of the claimant, and in the case where the claim is based upon loss of life, the citizenship of the deceased; relationship of the claimant to the deceased in death cases; time, place, and circumstances under which the injury or death occurred, including the identity of persons, officials, or agencies causing the injury or death,

... on account of the nationalization and other taking by Yugoslavia of property and of rights and in. terests in and with respect to property, which occurred between September x, 1939, and the date hereof."

Article I (a). Any excess over the claims determined to be valid is to be returned to the government of Yugoslavia. Article I (b).

${ }^{33}$ Much better information was obtained with respect to claims against Yugoslavia (sec note 32, stipra) than for claims against Italy. This can be attributed to the fact that the claims against Yugoslavia were largely for property expropriated since the war, where the claimants and the United States Government both knew immediately of the taking.

$\because 3$ But this was not the case in the Yugoslav settlement. See note 32 , supra.

' s5 Established by Act of July 3, I948, 62 STAT. 1240, 50 U. S. C. App. \$52001-20r3 (Supp. 1950). It has not been given authority to handle claims of this type. 
and the nature and extent of damages sustained. ${ }^{36}$ The State Department recommends that there be attached to the sworn statement affidavits and other documentary evidence supporting all of the material allegations therein. Further details concerning the nature of the evidence required in connection with the above can be obtained from the Department of State..$^{37}$

In the case of the Italian agreement, very few claims have been submitted to the Department of State. In present circumstances of United States aid to Europe, it would seem logical for the United States to place a time limit on the filing of such claims, and to return any unused balance to Italy. Such a procedure would, of course, require Congressional action. ${ }^{98}$

III

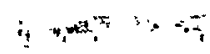

\section{United States Property In Italy}

A. The saisfaction of claims for damage to property in Italy belonging to, or in which there is an interest owned by, United States nationals, has certainly proved to be a long and hazardous process.

The Treaty, in dealing with this problem, begins with a clear dogmatic statement, simple of understanding. Article 78 , paragraph $\mathrm{r}$, provides that Italy is to "restore all legal rights and interests in Italy of the United Nations and their nationals as they existed on June 10, 1940, and shall return all property in Italy of the United Nations and their nationals as it now exists." 39

Paragraph 2 provides that the property is to be restored "free of all encumbrances and charges of any kind to which they may have been subject as a result of the war. . . .\$0 All measures imposed against United Nations property between June 10, 1940, and the coming into force of the Treaty are nullified.11 All transfers resulting from force or duress exerted by Axis governments and involving such property rights and interests belonging to United States nationals are to be invalidated by the Italian government. ${ }^{42}$

Unfortunately, the problem is too complicated to permit disposition by these simple rules. It was recognized that in many cases the property to be returned may have been totally destroyed or partially damaged as a result of the war. This problem has been the most difficult of solution, and has been the subject of successive negotiated clarifications. Paragraph 4 (a) of Article 78 provided that the Italian Government shall be responsible "for the restoration to complete good order of the

\footnotetext{
${ }^{30}$ Suggestions for preparing claims, for personal injury or loss of life, issued by the Department of State, January 5 , 1946.

${ }^{37}$ The procedures applicable to claims for damages to property are covered below. See note 80, infra.

${ }^{38}$ Other alternatives would be to cover the unused portion into miscellaneous receipts of the Treasury Department, or for Congress to provide that such funds shall be available for settlement of claims against other countries.

${ }^{30}$ Treaty of Peace with Italy, Part VII, Section I, Article 78, paragraph I.

${ }^{\circ}$ Treaty of Peace with Italy, Part VII, Section I, Article 78, paragraph 2.

1 Ibid.

12 Treaty of Peace with Italy, Part VI, Section I, Article 78, paragraph 3.
} 
property returned to United Nations nationals." ${ }^{33}$ The Article continues by providing that where the property cannot be returned, or where the property returned has been damaged, as a result of the war, Italy is to pay compensation "in lire to the extent of the sum necessary, at the date of payment" to purchase similar property or make good the loss suffered. ${ }^{44}$

Thus where no damage had been inflicted to the property it remains only for the Italian Government to return the property; where the property had been totally destroyed (a factory, owned by a United Nations national, completely demolished), then payment by Italy of two-thirds compensation in lire satisfies the Treaty requirements. But under the Treaty, what is the Italian Government's liability with respect to partially destroyed property: to restore to complete good order or to pay two-thirds of the sum necessary to make good the loss? The Treaty in two successive sentences provided for both procedures, but offers no guide for determining which procedure is to be followed.

The confusion was naturally one to be examined in the negotiations leading to the Lombardo Agreement. ${ }^{45}$ While the confusion was not confounded in that Agreement, it was not completely clarified. The Lombardo Agreement provided that the Government of Italy would expedite arrangements for the desequestration of and release of any unusual controls over the property, including cancellation of contracts for the sale of capital assets, or arrangements taken in accordance with official direction, which were not deemed to be in the best interest of such property or interests. ${ }^{46}$ The agreement provided further that the "requirement for restoration to good order" shall be followed in all cases where there has been "( $I$ ) deterioration of the physical property while under Italian control, and (2) where the physical property has suffered non-substantial damage as a result of acts of war." 47 In all other cases the requirement to compensate in lire to the extent of "two-thirds of the "sum necessary" is to apply, unless the Government of Italy determines to apply the requirement for the restoration to complete good order. ${ }^{48}$

The field of discussion had been narrowed. Under the Lombardo Agreement in one set of circumstances one had only to interpret the phrase "non-substantial damage." In another set of circumstances there still remained the problem of what to do in those cases where Italian management of the property had caused a serious deterioration in its value. For examplè, what was to happen where Italian management had resulted in sale of capital assets, which no longer could be traced? In such circumstances the requirement of "restoration to complete good order" 'lacks practical significance.

4 Treaty of Peace with Italy, Part VI, Section I, Article 78, paragraph 4 (a).

4 Ibid.

${ }^{25}$ See note 29, sipra.

${ }^{10}$ Memorandum of understanding between the Government of the United States of America and the Government of Italy regarding settlement of certain wartime claims and related matters (herein referred to as Memorandum of Understanding II), Article I6 (a), August I4, 1947. See note 29, supra.

IT Ibid. 
The clarifying language required further clarification. Accordingly in February of 1949 , it was agreed in an exchange of notes between the two governments: $:^{49}$

(a) Where at the date of payment the approved amount of a claim is $1,500,000$ lire or less, then the claim shall be considered as relating to deterioration of physical property while under Italian control or to non-substantial damage as a result of war, and in such circumstances Italy is required to pay the full amount of the claim.

(b) Where the approved claim at date of payment is in excess of $1,500,000$ lire, but two-thirds of the amount is less than $I_{5} 500,000$ lire, Italy is to pay 1,500,000 lire. In all other cases Italy is to pay two-thirds of the approved amount of the claim.

(c) Paragraphs (a) and (b) do not relieve the Government of Italy of the requirement of the Lombardo Agreement to release the property from any unusual controls, and to return the property irrespective of the possession or purported ownership thereof. However, where the property is not in existence, paragraphs (a) and (b) apply.

(d) A claimant may present separate claims where the properties for which he is claiming are not physically contiguous and do not form a part of a related whole.

B. Further provisions of the Treaty and subsequent clarifying agreements relating to claims for property in Italy should be examined, and consideration given to the procedures for filing claims, before review is made of the process in practice.

In the case of corporations or associations which are not United Nations nationals, but in which United Nations nationals hold, directly or indirectly, ownership interests, such nationals are to receive compensation for any damage or injury suffered by such corporation in accordance with the provisions applicable to cases where the property is directly owned by the United Nations national. ${ }^{50}$ In such cases, the compensation based on the total loss or damage shall bear the same proportion to such loss or damage as the beneficial interests of such nationals in the corporation or association bear to the total capital thereof..$^{51}$

The Treaty provided further that any compensation paid is to be free of taxes or other levies, and freely usable in Italy, but subject to Italian foreign exchange controls. ${ }^{82}$ All reasonable expenses incurred in Italy in establishing such claims are to be borne by the Italian Government..$^{53}$

A United Nations national is defined in the Treaty as a national of a United Nation at the coming into force of the Treaty, provided that such status was held as of the time of the armistice with Italy, September 3, I943. ${ }^{54}$ The Lombardo

${ }^{10}$ These notes have not been made public. They were exchanged between the United States Embassy at Rome and the Italian Ministry of Foreign Affairs.

${ }^{0}$ Treaty of Peace with Italy, Part VII, Section I, Article 78, paragraph 4 (b).

slbid.

sa Treaty of Peace with Italy, Part VII, Section I, Article 78, paragraph 4 (c).

ss Treaty of Peace with Italy, Part VII, Section I, Article 78, paragraph 5.

os Treaty of Peace with Italy, Part VII, Section I, Airticle 78, paragraph 9 (a).

The term "United Nations nationals" is defined" as also including "all individuals, corporations or associations which, under the laws in force in Italy during the war, have been treated as enemy."

An owner is defined as the United Nations national who is entitled to the property, including successor owner, provided such successor is also a "United Nations national." Treaty of Peace with Italy, Part VII, Section I, Article 78, paragraph 9 (a). 
Agreement provided that the individual must be a national as of the date of that agreement, rather than the date of the Treaty $;^{55}$ the Agreement of February, 1949, provided that a person may qualify as a United Nations national (insofar as United States nationals are concerned) either under the Treaty requirement or the Lombardo Agreement requirement. ${ }^{56}$

Under the Treaty any dispute arising with respect to claims for property in Italy is to be referred to a Conciliation Commission consisting of one representative of Italy and one of the Government of the United Nation concerned. If agreement cannot be reached by the Commission within three months, either Government may request the addition of one additional member selected by the two Governments. In the event that agreement cannot be reached on the appointment of a third member, the Government shall apply to the Ambassadors in Rome of the "Big Four" countries, who are to appoint the third member. And in the event they cannot agree (a more likely possibility today than at the time of the drafting of the Treaty), the Secretary-General of the United Nations may be requested by either party to make the appointment. 57

While the Lombardo Agreement did not deal with the Conciliation Commission, the Agreement of February, 1949, made the Treaty provision applicable to disputes arising under both the Lombardo Agreement and the Agreement of February, 1949. ${ }^{\text {.18 }}$

On June 29, 1950, the Italian-United States Conciliation Commission was formally established ${ }^{59}$ and issued rules of procedure for its operation. ${ }^{60}$ It is important to note that these rules provide that each of the two governments is to be represented before the Commission by a duly designated agent or deputy agent, and that the Commission will not receive or consider any statement or document unless presented through the respective agents or ordered produced by the Commission. ${ }^{01}$ Proceedings before the Commission are initiated by the formal filing with the Secretariat of the Commission of a Petition signed by the agent of the claiming government. ${ }^{62}$ The petition must contain full information concerning the claimant on whose behalf the proceedings are initiated; a clear and concise statement of the facts in each case; a clear and concise statement of the principles of law upon which the dispute is based;

\footnotetext{
${ }^{55}$ Memorandum of Understanding II, Article V, paragraph 18.

"See note 49 , supra.

57 Treaty of Peace with Italy, Part IX, Article-83, paragraph I. The Treaty provides for a separate conciliation commission for each United Nation which may be involved in a dispute. Thus there is an Anglo-Italian Conciliation Commission, a French-Italian Conciliation Commission, etc. This is not a very workable arrangement. It is to be hoped that the Japanese Treaty, if and when finalized and signed, will provide for one conciliation commission for all disputes, in which event it should probably consist of nationals of neutral countries not parties to the Treaty.

ss See note 49̀, supra.

${ }^{50}$ The American member is Emmett A. Scanlan, Jr.; the Italian member is Antonio Sorrentino.

${ }^{10}$ Rules of Procedure of the Italian-United States Conciliation Commission, adopted and promulgated in Rome on June 29, 1950. The Commission has its seat in Rome. Its rules have not, as of the date of writing, been published officially in this country.

${ }^{a 1}$ Rules of Procedure, Article 4.

6s Rules of Procedure, Article 7, paragraph (a).
} 
and a complete statement setting forth the purpose of the Petition and the relief requested. ${ }^{63}$ Upon the filing of a Petition, an Answer signed by the agent of the responding government must be filed within $3^{0}$ days. ${ }^{64}$ The Answer must contain a statement of the facts presented in the Petition of the claiming government which are admitted as true, a statement of any other element of fact upon which the responding government is relying in its defense of the case, and a clear concise statement of the principles of law upon which the dispute is based. ${ }^{65}$ The complaining government may file a reply to the Answer by making a written request within ${ }_{5}$ days after the filing of the Answer for an order establishing the time limit for filing the reply. ${ }^{66}$ The reply may deal with the allegations in the answer which raise factual or legal defenses or new material not alleged or adequately treated by the complaining government in the petition. ${ }^{67}$ Following the common law procedure of rejoinders, surrejoinders, rebutters, and surrebutters, the rules provide that when the respondent government considers that a counter-reply is necessary it shall, within I5 days after the filing of the reply, make a written request to the Commission for an order establishing the time limit for filing the counter-reply. ${ }^{68}$ The Commission will hear oral testimony only in exceptional cases, upon order of the Commission authorizing its admission. ${ }^{69}$ The Commission may order officials of either government to receive sworn testimony of a witness taken in answer to written questions prepared by the agent of either government and approved by the Commission. ${ }^{70}$ Such testimony is to be given under oath either in accordance with the terms of the law of the place where such testimony is to be given or in accordance with the laws of the country of which the witnesses are nationals, as the Commission shall-determine in each particular instance. ${ }^{71}$ The Commission may also request the agents to develop their arguments orally after they have completed the submission of proof, and the agents may file a written citation of legal authorities. ${ }^{\mathbf{2}}$ Briefs may be submitted by the agent of either government unless the Commission directs otherwise. ${ }^{73}$ Proceedings before the Commission, both oral and written, may be in either English or Italian. ${ }^{74}$ If within three months after a dispute has been referred to the Commission it has been unable to reach an agreement, the two members of the Commission or either of them may issue a "Procés-Verbal of Non-Agreement."75 The agents are then required to notify their governments of such issuance of a "ProcésVerbal of Non-Agreement."76

In such cases a third member of the Commission appointed pusuant to Article 83 of the Treaty is to preside at all hearings or other sittings which may be held. ${ }^{77}$

\footnotetext{
os Ibid.

5 Ibid.

${ }^{\circ}$ Ibid.

os Rules of Procedure, Article 8, paragraph (d).

${ }^{\circ}$ Id., Article Io, paragraph (a).

${ }^{71}$ Id., Article 10, paragraph (d).

${ }^{73}$ Id., Article II, paragraph (c).

TE Id., Article I4.

${ }^{7}$ Id., Article I5, paragraph (b).
}

\footnotetext{
${ }^{84}$ Rules of Procedure, Article 8, paragraph (a).

${ }^{68}$.Rules of Procedure, Article 8, paragraph (c).

${ }^{70}$ Id., Article Io, paragraph (b).

${ }^{72}$ Id., Article II, paragraph (a).

74Id., Article 12.

${ }^{70}$ Id., Article $\mathrm{x}_{5}$, paragraph (a).
} 
The proceedings before the Commission of three members are limited to the points on which no agreement can be reached by the Commission of two members, agreements on points previously reached by the two members being final and non-reviewable. ${ }^{78}$ Decisions by the Commission of three members are to be by majority vote, although the member in the minority has the right to deposit with the Secretariat a statement of the reasons for his dissent. ${ }^{79}$

In actual execution, the satisfaction of claims of United States nationals with respect to property in Italy has been a slow process. The Italian Government, in accordance with the terms of the Lombardo Agreement, designated the Ministry of Finance as the agency of the Italian Government responsible for dealing with such claims. To assist United States nationals, the Department of State appointed a special section in the Embassy in Rome to assist in the presentation of claims.

Technically, under Article 76 , paragraph 82 of the Treaty, claims may be filed directly with the Italian Government. However, experience indicates that the Italian Government does not accept claims unless filed by the United States Embassy at Rome. In any event a claimant is better advised to submit the claim to the Department of State, for transmission to the United States Embassy at Rome, or directly to the Embassy.

In submitting claims for loss or damage to property, the Department of State recommends ${ }^{80}$ that the claim contain in narrative form a clear chronological statement of the essential facts relating to citizenship of the claimant or claimants; a full description of the property in question, and its exact location when the loss occurred; the time and manner of the acquisition of the claimant's ownership of the property or other interest therein; the action taken against the property which is considered as giving rights to a claim against the Italian Government; the identification of persons; officials, agencies, or forces taking such action, and the dates when the action was taken; and the nature and amount of the damage resulting from the action concerning which a complaint is being filed. There should also be submitted evidence in support of the sworn statements of the claimant or claimants. Full details concerning the nature of the evidence required can be obtained from the Department of State.

C. It was only in the late spring of $195^{\circ}$ that Italy satisfied any claims. The establishment of the Conciliation Commission assisted considerably in expediting the consideration and the payment of claims. Thus the United States referred cases to the Commission on the ground that the Italian Government had not made any disposition of a claim long on file with it. However, internal Italian Government pressure probably accounts for the activity generated last spring. The Italian Ministry of Foreign Affairs, embarrassed in its relations with the United States by reason of the long period of inactivity, undoubtedy brought pressure on the Ministry of Finance.

\footnotetext{
${ }^{78}$ Id., Article 15, paragraph (c).

${ }^{70}$ Id.. Article 16.

${ }^{80}$ Suggestions for preparing claims for loss of or damage to property, issued by the Department of State, December 20, 1945.
} 
The available statistics reveal the following record. The United States Embassy at Rome had, as of December 3, I950, received a total of r39I claims (including those forwarded to it by the Department of State) with an alleged lire value of 52,628,987,446. Of these cases $88 \mathrm{r}$ had been submitted to the Italian Government, of which 69 had been accepted, I2 paid, and 30 rejected. Six of the rejected claims have been filed with the Conciliation Commission (including cases referred to it by the United States Embassy where the Italian Government had, in the Embassy's opinion, unduly procrastinated in disposing of the claims). The total value of the claims paid reflects a considerably better record than the number. Thus the Italian Government as of December 3r, I950, paid out $\mathrm{x}, 8 \mathrm{I} 6, \mathrm{I} 95,408$ lire (conversion to dollars at that time being 624 lire to the dollar).

\section{IV}

ConcLusion

The general conclusion that can be drawn, without implying any criticism to either Government, is that a better way ought to be found to deal with such claims for property damages. The disposition of claims for personal injury cases in the Lombardo Agreement provides a more practicable framework for handling the problem.

Such a procedure would require the following steps:

(I) The United States Government would require its nationals to file claims with it by a specified date.

(2) The United States would then negotiate with the other Government for a lump sum settlement, whether the settlement should be in dollars or in the currency of the other Government depending on the nature of the claims.

(3) Out of such sum so obtained, the United States Government would determine the validity of claims, and make payment accordingly.

Obviously, such a procedure is not now open to the settlement of claims under the Italian Treaty, but a comparable procedure is available. United States claimants could form an association comparable to the Foreign Bond Holders Protective Council, Inc., which would appoint a committee to evaluate such claims, negotiate a lump sum settlement with the Italians, binding on all members of the association, and then provide for the satisfaction of the claims through its own procedures.

In any event, the lump-sum settlement procedure deserves consideration with respect to the negotiation of the Japanese Treaty of Peace. At least it can be expected that the United States negotiators will bear in mind that the procedure established in the favorable circumstances of United States-Italian relations is not a very satisfactory one. That procedure is not one likely to bring relatively quick satisfaction to the United States claimants, nor one designed to remove the troublesome claims issue from being an undesirable source of conflict between the United States and the other Government concerned. 